\title{
Frailty in Elderly and Care
}

\section{Daniella Pires Nunes ${ }^{1,3 *}$, Tábatta Renata Pereira de Brito ${ }^{1,3}$ and Yeda Aparecida de Oliveira Duarte ${ }^{2,3}$}

${ }^{1}$ Ph.D Student of School of Nursing, University of São Paulo, Brazil

${ }^{2}$ Professor of Department of Medical Surgical Nursing, School of Nursing, University of São Paulo, Brazil

${ }^{3}$ Health, well being and Aging Study (SABE Study), Brazil

Frailty is a common syndrome that is associated with vulnerability to poor health-outcomes. Frail elderly people have increased risk of falls, disability, hospitalization and death, resulting in burden to individuals, their families, health care services and society [1-3].

Nowadays, there are many conceptions of frailty that reflect an urgent necessity of consensus to define this matter and make its tracking and treatment effective [4,5]. Mitnitski et al. [2] developed a Frailty Index which is measured by the amount of accumulation of deficits over time, including disability, physical and cognitive impairments, psychosocial risk factors, diseases, fall, delirium and urinary incontinence. Fried et al. [1] operationalized a frailty conception via phenotype compound by weight loss, exhaustion, weakness, low physical activities and slowness. An elderly person with one or two components is classified as prefrail, more than three is considered frail.

Kanne et al. [5] points out through a systematic review that there is a variation between prevalence estimates according to adopted definitions. In the studies based on Frailty Index, the prevalence was between $14.6 \%$ and $44.7 \%$, whilst the ones focused on phenotype of frailty showed $6.9 \%$ to $42.7 \%$ and corroborates that the syndrome of frailty is associated with comorbidity, falls, functional decline, disability and necessity of hospitalization.

Research has shown that frailty is a distinct condition of disability and comorbidity, although it can occur some overlap between these two conditions [6]. Frail individuals generally show other chronic diseases and higher probability of developing sequelae or disabling conditions $[1,7]$. Both are associated to a higher necessity of care and use of health services, what, in general, result in an increase of healthcare costs, besides significant worsening in the elderly's life quality and their relatives [8]

Frailty process is considered reversible and subject to prevention since precocious identification and adoption of pro-active actions that avoid or postpone the occurrence of adverse outcomes in health [9]. Therefore, many efforts are being built in order to identify the syndrome in advance. In this case, Xue et al. [10] verifies that weakness may act as a warning sign of increasing vulnerability in early frailty development and weight loss; and exhaustion may help to identify the risk for rapid adverse progression.

Precocious stages of frailty are more frequently observed in elderly people that reside in communities, what emphasizes the necessity of tracking the syndrome in the primary attention $[1,9]$. For this reason, it is necessary that professionals incorporate in their daily clinical practices the evaluation of frailty syndrome, considering individual's particularities within social environment [11].

Vigilance towards frail elderly people represents a big challenge for social and health institutions, family and society. Longitudinal studies applied in São Paulo, Brazil, SABE Study (an acronym in Spanish and Portuguese for Health, Well being and Aging), verified that frail elderly people are more dependent on personal care and show more limitation for an independent community life. Consequently, they demand more vigilance and use of health services, mainly the emergency ones. Studies also showed that these sort of elderly people belonged to dysfunctional families and, therefore, with more limitations to care them, besides carers overloaded, what, in deep analysis, affects the quality of assistance to this group [12].

After all this, emerges a necessity of an assistance model able to preconize prevention of frailty and allows priority to systemic attendance to frail elderly people and their relatives inside the community, thus contributing to a survival with better quality.

\section{References}

1. Fried LP, Tangen CM, Walston J, Newman AB, Hirsch C, et al. (2001) Frailty in older adults: evidence for a phenotype. J Gerontol A Biol Sci Med Sci 56 : M146-M156.

2. Mitnitski AB, Mogilner AJ, Rockwood K (2001) Accumulation of deficits as a proxy measure of aging. ScientificWorldJournal 1: 323-336.

3. Fairhall N, Langron C, Scherrington C, Lord SR, Kurrle SE, et al. (2011) Treating frailty-a pratical guide. BMC Med 9: 83.

4. Gobbens RJ, Luijkx KG, Wijnen-Sponselee MT, Schols JM (2010) Toward a conceptual definition of frail community dwelling older people. Nurs Outlook 58: 76-86.

5. Kane RL, Talley KMC, Shamliyan T, Pacala JT (2011) Common syndromes in older adults related to primary and secondary prevention [internet]. Rockville (MD): Agency for Healthcare Research and Quality.

6. Fried LP, Ferrucci L, Darer J, Williamson JD, Anderson G (2004) Untangling the concepts of disability, frailty and comorbidity: implications for improved targeting and care. J Gerontol A Biol Sci Med Sci 59: 255-263.

7. Ottenbacher KJ, Ostir GV, Peek MK, Snih SA, Raji MA, et al. (2005) Frailty in older Mexican Americans. J Am Geriatr Soc 53: 1524-1531.

8. Rochat S, Cumming RG, Blyth F, Creasey H, Handelsman D, et al. (2010) Frailty and use of health and community services by community-dwelling older men: the Concord Health and Ageing in Men Project. Age Ageing 39: 228-233.

9. Gill TM, Gahbauer EA, Allore HG, Han L (2006) Transitions between frailty states among community-living older persons. Arch Intern Med 166: 418-423.

10. Xue QL, Bandeen-Roche K, Varadhan R, Zhou J, Fried LP (2008) Initial manifestations of frailty criteria and the development of frailty phenotype in the Women's Health and Aging Study II. J Gerontol A Biol Sci Med Sci 63: 984-990.

11. Lacas A, Rockwood K (2012) Frailty in primary care: a review of its conceptualization and implication for pratice. BMC Medicine 10: 4.

12. Duarte YAO, Nunes DP, Corona LP, Lebrão M (2010) Como estão sendo cuidados os idosos frágeis de São Paulo? A visão mostrada pelo Estudo SABE (Saúde, bem estar e envelhecimento). In: Camarano AA. (org.). Cuidados de longa duração para a população idosa: um novo risco social a ser assumido? Rio de Janeiro: IPEA, 123-144.

*Corresponding author: Daniella Pires Nunes, Departamento de Epidemiologia - Estatística, University of São Paulo, Brazil, Tel: 55-11- 30617931; E-mail: dpiresnunes@yahoo.com.br

Received March 19, 2012; Accepted March 21, 2012; Published March 30, 2012

Citation: Nunes DP, de Brito TRP, de Oliveira Duarte YA (2012) Frailty in Elderly and Care. J Gerontol Geriat Res 1:e108. doi:10.4172/2167-7182.1000e108

Copyright: (C) 2012 Nunes DP, et al. This is an open-access article distributed under the terms of the Creative Commons Attribution License, which permits unrestricted use, distribution, and reproduction in any medium, provided the original author and source are credited. 